\title{
PENERAPAN GOOD GOVERNANCE PADA KEPENGURUSAN PONDOK PESANTREN PUTRI AL-AMIEN
}

\author{
Agus Miftakus Surur ${ }^{1}$, Kharisma Nur Cholifah ${ }^{2}$ \\ surur.math@gmail.com \\ ${ }^{1}$ Institut Agama Islam Negeri (IAIN) Kediri;
}

\begin{abstract}
Good governance is the way in organizing resources and solve the problems of the public. Good governance arose due to dissatisfaction on the performance of Government organizer of public affairs. Good governance is needed in seeking and maintaining a social life, respect of the rights and obligations of every Member of society to realize. Boarding schools are also included in community groups. Each boarding schools must have had the caregiver, the organizational structure, students, and the code of conduct as well as the conditions that must be observed. There has to be cooperation from all parties so that community life created an orderly and harmonious. So, the principles of good governance should be applied in the system of governance. In this study, using this type of qualitative research. While the approach used, namely the approach of case studies. This type of approach to study intensively on one object of study it as a case that is about the application of good governance on boarding schools Daughter Al-Amien. As a result, the organizational system in boarding schools Daughter Al-Amien looks pretty good. Stewards still provide leniency on students to voice your opinions and defend themselves. Participation and responsibilities of students themselves as a society have also been quite good. The Naat dare infringe but remain ready to accept any consequences.
\end{abstract}

Keywords: Good Governance, Trustees, Boarding Schools

\begin{abstract}
Abstrak
Good governance merupakan tata cara dalam mengatur sumber daya dan memecahkan masalah-masalah publik. Good governance muncul karena adanya ketidakpuasan pada kinerja pemerintahan penyelenggara urusan publik. Good governance diperlukan dalam mengupayakan dan menjaga kehidupan bermasyarakat, menghargai hak dan menyadari kewajiban setiap anggota masyarakat. Pondok pesantren juga termasuk dalam kelompok masyarakat. Setiap pondok pesantren pasti memiliki pengasuh, struktur kepengurusan, santri, dan tata tertib serta ketentuan yang harus dipatuhi. Harus ada kerjasama dari semua pihak agar tercipta kehidupan bermasyarakat yang teratur dan harmonis. Sehingga, prinsip-prinsip good governance harus diterapkan dalam sistem kepengurusan tersebut. Dalam penelitian ini, menggunakan jenis penelitian kualitatif. Sedangkan pendekatan yang digunakan yaitu pendekatan studi kasus. Pendekatan jenis ini untuk mempelajari secara intensif pada satu objek yang mempelajarinya sebagai suatu kasus yaitu tentang Penerapan good governance pada Pondok Pesantren Putri AlAmien. Hasilnya, sistem kepengurusan di Pondok Pesantren Putri Al-Amien terlihat cukup baik. Para pengurus tetap memberikan kelonggaran pada santri untuk menyuarakan pendapat dan membela diri. Partisipasi dan tanggung jawab dari santri sendiri sebagai masyarakat juga sudah cukup baik. Para santri berani melanggar tapi tetap siap menerima setiap konsekuensinya.
\end{abstract}

Kata Kunci: Good governance, Pengurus, Pondok Pesantren 


\section{PENDAHULUAN}

Masalah pemerintahan adalah suatu kenyataan yang tak dapat dihindarkan dalam hidup setiap masyarakat. Pemerintah merupakan harapan dan peluang untuk mewujudkan hidup yang sejahtera dan berdaulat melalui pengelolaan kebebasan dan persamaan yang di miliki oleh masyarakat. Pada sisi lain pemerintah adalah tantangan dan kendala bagi suatu masyarakat terutama ketika pemerintah terjauhkan dari pengalaman etika pemerintah. Suatu masyarakat tanpa pemerintah adalah sebuah kekacauan massal. Di dalam masyarakat manusia beradab di perlukan lebih banyak peraturan, diperlukan juga lebih banyak upaya dan kekuatan untuk menjamin bahwa peraturan-peraturan itu di taati (Dwiyanto, 2009).

Good governance adalah mekanisme, praktek dan tata cara pemerintahan dan warga dalam mengatur sumber daya serta memecahkan masalah-masalah publik. Dalam konsepnya pemerintah hanya menjadi salah satu aktor dan tidak selalu menjadi aktor yang menentukan. Pemerintah berperan sebagai pendorong terciptanya lingkungan yang mampu memfasilitasi pihak lain di komunitas. governance menuntut yang lebih besar pada warga, antara lain untuk memonitor akuntabilitas pemerintah itu sendiri (Sjaifudian, 2003).

Lahirnya wacana good governance berakar dari penyimpangan-penyimpangan yang terjadi dalam praktek pemerintahan, seperti korupsi, kolusi dan nepotisme (Ubaedillah, 2007). Selain itu konsep good governance ini muncul karena adanya ketidakpuasan pada kinerja pemerintahan yang selama ini dipercaya sebagai penyelenggara urusan publik. Pendekatan penyelenggaraan urusan publik yang bersifat sentralis, non partisifatif serta tidak akomodatif terhadap kepentingan publik pada rezim-rezim terdahulu, harus diakui telah menumbuhkan rasa tidak percaya dan bahkan antipati pada rezim yang berkuasa (Santosa, 2008).

Menurut Edelman, hal seperti diatas merupakan era anti birokrasi, era anti pemerintah, Penerapan prinsip-prinsip good governance sangat penting dalam pelaksanaan pelayanan publik untuk meningkatkan kinerja aparatur negara. Hal ini disebabkan karena pemerintah merancang konsep prinsip-prinsip good governance untuk meningkatkan potensi perubahan dalam birokrasi agar mewujudkan pelayanan publik yang lebih baik, disamping itu juga Masyarakat masih menganggap pelayanan 
publik yang dilaksanakan oleh birokrasi pasti cenderung lamban, tidak profesional, dan biayanya mahal (Santosa, 2008).

Pendapat tentang buruknya semua pelayanan yang dilaksanakan birokrasi menurut Pandji Santosa merupakan pengaburan makna birokrasi yang berkembang di masyarakat dan terus berlangsung oleh sikap diam masyarakat (Santosa, 2008). Awalanya good governance digunakan dalan dunia usaha dan adanya desakan untuk menyusun sebuah konsep dalam menciptakan pengendalian yang melekat pada korporasi dan manajemen profesionalnya (Nugroho, 2004). Namun sekarang good governance atau pemerintahan yang baik sangat diperlukan dalam mengupayakan dan menjaga kehidupan bermasyarakat yang baik, menghargai hak dan menyadari kewajiban setiap anggota masyarakat. Masyarakat adalah sekelompok orang yang tinggal dan menetap dalam suatu wilayah. Sebagaimana disadari bahwa sebuah pondok pesantren juga termasuk dalam kelompok masyarakat.

Berdasarkan hasil penelitian terdahulu, telah dilakukan beberapa penelitian untuk menguji dan membuktikan secara empiris penerapan good governance (Azlim, Darwanis, \& Bakar, 2012; Fitriana, Irianto, \& Mulawarman, 2018; Rahayu, 2014; Rasul, 2009; Trisnaningsih, 2007; Wiguna \& Putra, 2017; Yusniyar, Darwanis, \& Abdullah, 2016) diberbagai bidang, baik dalam kepengurusan (Atiqullah, 2012; Ja'far, 2018; Wardianto \& Hendrati, 2014) dan kepemimpinan kiai (Arifin, 2015; Asifudin, 2016; Sari \& Yani, 2013; US., 2010; Wulandari, 2014) di pondok pesantren. Perbedaan dengan penelitian sebelumnya yaitu peneliti ingin menelusuri tentang sistem kepengurusan Pondok Pesantren Putri Al-Amien. Serta ingin mengetahui penerapan good governance pada kepengurusan Pondok Pesantren Putri Al-Amien.

\section{METODE PENELITIAN}

Penelitian ini, menggunakan jenis penelitian kualitatif, agar dapat mendiskripsikan dengan jelas tentang "Penerapan good governance pada Kepengurusan Pondok Pesantren Putri Al-Amien”. Penelitian kualitatif yaitu penelitian yang menentukan pada keadaan sebenarnya dari suatu objek yang diteliti. Lexi J. Moleong menjelaskan "penelitian kualitatif sebagai prosedur penelitian yang menghasilkan data deskriptif berupa kata-kata tertulis atau lisan dari orang-orang dan perilaku yang dapat diamati” (Moleong, 2011). 
Dengan demikian maka peneliti berusaha untuk memberikan pemaparan tentang segala sesuatu yang menjadi objek penelitian dalam bentuk deskriptif kalimat sesuai dengan keadaan sesungguhnya dari suatu objek. Penelitian yang bersifat deskriptif menurut Suharsimi Arikunto lebih tepat apabila menggunakan penelitian kualitatif (Suharsimi Arikunto, 1993). Sedangkan pendekatan yang digunakan yaitu pendekatan studi kasus. Pendekatan jenis ini untuk mempelajari secara intensif pada satu objek yang mempelajarinya sebagai suatu kasus yaitu tentang Penerapan good governance pada Pondok Pesantren Putri Al-Amien.

Metode kualitatif menurut Bogdan dan Taylor, sebagaimana yang dikutip oleh Lexi J. Meleong bahwa "metode kualitatif adalah sebagai prosedur penelitian yang menghasilkan data deskriptif berupa kata-kata tertulis atau lisan dari orang-orang dan perilaku yang dapat diamati” (Moleong, 2011). Sedangkan jenis penelitian yang digunakan adalah studi kasus. Arikunto memaparkan bahwa dalam penelitian ini peneliti mencoba untuk mencermati individu secara mendalam terkait kejadian individu atau unit (Suharsini Arikunto, 2005). Senada dengan pengertian diatas, Santoso mengatakan bahwa studi kasus adalah penelitian yang pada umumnya bertujuan untuk mempelajari secara mendalam terhadap suatu individu, kelompok, lembaga atau masyarakat tertentu, tentang latar belakang, keadaan sekarang atau interaksi yang terjadi (Santoso, 2005). Dalam hal ini peneliti turun ke lokasi penelitian terlebih dahulu, peneliti melakukan survey penjajakan proses pencatatan data.

Kehadiran peneliti pada penelitian kualitatif berbaur dan menyatu dengan subyek penelitian (informan) sehingga kehadiran peneliti tidak dapat diwakilkan oleh angket atau tes. Selama penelitian berlangsung dilakukan pengamatan dan wawancara dengan mendalam untuk mengeksplorasikan fokus penelitian (Putra \& Lisnawati, 2012). Jadi dapat dikatakan bahwa kehadiran peneliti dalam penelitian kualitatif itu sangat penting.

Sebagaimana telah tertera dalam Buku Pedoman Karya Ilmiah STAIN Kediri bahwa kehadiran peneliti di lokasi penelitian adalah untuk menemukan dan mengeksplorasi data-data yang terkait dengan fokus penelitian yang didekati dengan observasi langsung (Kediri, 2009). Menurut Bogdan dalam Lexi J. Moleong mendefinisikan mendefinisikan kehadiran peneliti dalah penelitian yang bercirikan interaksi sosial yang memakan waktu yang cukup lama antara peneliti dengan subyek 
penelitian dan selain itu data dalam bentuk catatan lapangan dikumpulkan secara sistematis (Moleong, 2011). Dalam hal ini fokus penelitian adalah kepemimpinan Pengurus dalam Pondok Pesantren Putri Al-Amien Ngasinan Kediri.

Data dalam penelitian ini adalah semua data atau informasi yang diperoleh dari informan yang dianggap mengetahui secara rinci dan jelas mengenai fokus penelitian yang diteliti. Berdasarkan sumbernya peneliti menggunakan data sumber data primer yaitu data yang diperoleh atau dikumpulkan oleh peneliti secara langsung dari sumber datanya yaitu pengurus dan salah satu santri di Pondok Pesantrean Putri Al-Amien Ngasinan Kediri.

Selain diperoleh melalui informan, data juga diperoleh dari hasil observasi seperti pengamatan secara langsung kinerja kepengurusan yang ada di Pondok AlAmien misalnya melakukan absensi setiap kegiatan, dan ketertiban para santri putri dalam melaksanakan kegiatan tersebut. Selanjutnya dokumentasi yang menunjang terhadap data-data tertulis seperti nama-nama pengurus, sarana dan prasarana dan sejarah berdirinya pondok. Sesuai dengan judul, maka sumber datanya disebut responden. Menurut Suharsimi Arikunto, bahwa responden adalah orang yang merespon atau menjawab pertanyaan- pertanyaan peneliti, baik pertanyaan tertulis maupun lisan (Suharsimi Arikunto, 1993). Adapun yang menjadi responden dalam penelitian ini adalah :

a. Pengurus, dengan pertanyaan singkat seperti sejak kapan menjabat, usaha untuk meningkatkan kualitas kepengurusan, aturan yang sudah berjalan, bagaimana penerapan good governance dalam kepengurusan.

b. Santri putri, dengan pertanyaan singkat mengenai kepengurusan pengurus apakah sesuai dengan kondisi dan apakah semua santri juga menaati peraturan yang dibuat.

Pengumpulan data adalah prosedur yang sistematis dan standar untuk memperoleh data yang diperlukam selalu ada hubungan antara metode pengumpulan data dengan masalah penelitian yang ingin dipecahkan. Menurut Arikunto, teknik pengumpulan data adalah cara-cara yang dapat digunakan oleh peneliti untuk mengumpulkan data. Cara menunjuk pada suatu yang abstrak, tidak dapat diwujudkan dalam benda yang kasat mata, tetapi hanya dapat dipertontonkan penggunaanya. Adapun yang terdaftar sebagai metode-metode penelitian adalah angket 
(questionnaire), wawancara (interview), pengamatan (observation), ujian atau tes (test), dokumentasi (documentation) dan lain sebagainya (Suharsimi Arikunto, 1993). Adapun dalam penelitian ini, peneliti menggunakan teknik: pengamatan (observation), wawancara (interview) dan dokumentasi (documentation).

Setelah semua data telah terkumpul dari berbagai metode yang digunakan ataupun dengan teknik observasi, wawancara dan dokumentasi, maka langkah selanjutnya adalah mentabulasikan data yang kemudian diadakan penganalisaan dengan jenis data yang terkumpul. Dengan demikian analisis ini dilakukan setelah meninggalkan lapangan. Analisis data adalah proses mengatur urusan data, pengorganisasiannya kedalam suatu pola, kategori dari suatu uraian dasar sehingga dapat ditemukan tema dan dapat dirumuskan hipotesis kerja seperti yang disarankan oleh data. Hal ini dimaksudkan untuk mendapatkan fakta dengan jalan mencari data yang ditimbulkan oleh proses masalah tertentu, kemudian diambil suatu kesimpulan.

Oleh karena itu analisa yang digunakan adalah analisis deskripsif kualitatif, artinya peneliti berusaha mendeskripsikam dan mengintrespestasikan kondisi atau hubungan yang, pendapat yang sedang tumbuh, proses yang sedang berlangsung, akibat yang terjadi atau kecenderungan yang sedang berkembang. Sesuai dengan jenis penelitian kualitatif maka analisa data adalahpenilaian terhadap gejala yang terjadi di lapangan. Secara umum analisa data dilakukan peneliti sejak memasuki latar penelitian dengan cara menelaah setiap data yang dikumpulkan, baik data yang diperoleh melalui observasi, wawancara, maupun dokumentasi yang berhubungan dengan penerapan good governance pada kepengurusan Pondok Pesantren Putri AlAmien.

Data yang telah diperoleh akan dianalisis secara kualitatif. Teknik analisis data yang digunakan adalah reduksi data, penyaji data dan Verifikasi Data dan Penarikan Kesimpulan. Analisis data dalam penelitian kualitatif dilakukan pada saat pengumpulan data berlangsung dan setelah selesai pengumpulan data langsung, dan setelah selesai pengumumpulan data dalam periode tertentu. Pada saat wawancraa, peneliti sudah melakukan analisis terhadap jawaban informan. Apabila jawaban informan, setela di analisis belum lengkap, mak peneliti akan melanjutkan memberikan pertanyaan-pertanyaan berikut sampai tahap tertentu diperoleh data yang lebih krediabel (Moleong, 2011). 


\section{HASIL PENELITIAN DAN PEMBAHASAN}

Pendapat pertama menekankan sistem pada komponennya, "sistem adalah kumpulan dari elemen-elemen yang berinteraksi untuk mencapai suatu tujuan tertentu”. Pendapat kedua menekankan sistem pada prosedurnya, "system adalah suatu jaringan kerja dari prosedur-prosedur yang saling berhubungan, berkumpul bersama-sama untuk melakukan suatu kegiatan atau untuk menyelesaikan suatu sasaran tertentu" (Andalia \& Setiawan, 2015).

Menurut KBBI yang dimaksud dengan kepengurusan adalah seluk beluk yang berhubungan dengan tugas pengurus untuk mencapai kesepakatan pada suatu organisasi tertentu. Sistem kepengurusan Pondok Pesantren Putri Al-Amien, terdapat kekurangan dalam jumlah pengurus, dikarenakan banyak dari santri yang tidak mau menjadi pengurus ketika ditunjuk oleh Gus Fariz, sebab system kepengurusan disana berlaku selama masih bermuqim di pondok tersebut, jadi dalam hal mengurusi santri masih dalam kepengurusan. Seharusnya pengurus lebih banyak lagi, agar kegiatan pengajian belajar berjalan lancar. Terdapat dibeberapa gedung yang kekurangan pengurus seperti gedung $\mathrm{C}$, kekurangan pengurus dalam hal pendidikan karena hanya ada 1 orang yang mengkoordinasi seharusnya terdapat minimal 2 pengurus agar tidak keteteran dalam kepengurusan, gedung $\mathrm{D}$ tidak adanya pengurus perlengkapan dan Gedung B kekurangan pengurus perlengkapan.

Sebagaimana dikatakan oleh salah satu santri, sistem kepengurusan di pondok ini terlaksana kurang baik, seperti piket gedung harian belum berjalan dengan baik. Hal ini terjadi karena pengurus kualahan dan kurangnya kesadaran dari hati santri. Selain itu pengurus yang ada di pondok ini juga masih kurang, hal ini disebabkan karena banyak santri yang tidak mau menjadi pengurus ketika ditunjuk oleh gus Faris. Hal tersebut terjadi karena sistem kepengurusan disana berlaku selama menjadi santri dan itu yang membuat teman-teman berat untuk menerimanya. Menurutnya seharusnya kepengurusan disana harus ada priodenya agar santri mengetahui pada saat periode siapa kepengurusan itu terlaksana dengan baik.

Untuk ketua pondok di Pondok Pesantren Al-amien langsung diketuai oleh Gus Faris. Dapat dikatakan bahwa tidak ada ketua pondok dari pihak pengurus sendiri, 
melainkan langsung pengasuh, kalau dulu ketua pondoknya dari santri jadi yang mengkoordini lebih mudah jika dari santri. Jika ada permasalahan, maka diselesaikan dengan cara musyarawah bersama lewat sebelum musyawarah koordinator dulu, koordinator keamanan, pendidikan, perlengkapan. Biasanya koordinator dulu kalau ada masalah, baru nanti dibahas ketika ada ada evaluasi pengurus atau rapat pengurus. Dalam bidang pendidikan di Pondok Pesantren al-Amien sudah berjalan dengan baik. Semua santri mengikuti kegiatan dengan ritun terutama ketika diniyah dan pengajian kitab. Santri sangat antusias dalam melakukannya. Apalagi ketika malam minggu santri sangat semangat untuk mengikuti kegiatan diba'an atau pun khitobah yang dilakukan setiap malam minggu secara bergantian.

Good governance adalah mekanisme, praktek dan tata cara pemerintahan dan warga dalam mengatur sumber daya serta memecahkan masalah-masalah publik. Dalam konsepnya pemerintah hanya menjadi salah satu aktor dan tidak selalu menjadi aktor yang menentukan. Pemerintah berperan sebagai pendorong terciptanya lingkungan yang mampu memfasilitasi pihak lain di komunitas. Governance menuntut yang lebih besar pada warga, antara lain untuk memonitor akuntabilitas pemerintah itu sendiri (Sjaifudian, 2003).

Untuk meralisasikan pemerintahan yang professional dan akuntabel yang bersandar pada prinsip-prinsip good governance Lembaga Administrasi Negara (LAN), dan Masyarakat Transparansi Indonesia (MTI) (Ubaedillah, 2007), merumuskan sembilan aspek fundamental (Asas) dalam good governance yang harus diperhatikan, yaitu; Partisipasi (participation); Penegakan hukum (rule of law); Transparansi (transparency); Responsive (responsiveness); Orientasi kesepakatan (consensus orientation); Kesetaraan (equite); Efiktivitas (effectivenness) dan Efisiensi (eficiency); Akuntabilitas (accountability); Visi strategis (strategic vision).

Kepengurusan yang baik sangat diperlukan dalam mengupayakan dan menjaga kehidupan santri agar terciptanya kehidupan yang baik, menghargai hak dan menyadari kewajiban setiap santri. Berdasarkan penelitian yang peneliti lakukan, maka disini peneliti menjelaskan prinsip- prinsip good governace yang diterapkan di Pondok Pesantren Putri Al- Amien, yaitu sebagai berikut:

1. Akuntabilitas (Bertanggung jawab) 
Asas akuntabilitas adalah pertanggungjawaban pejabat publik terhadap masyarakat yang memberinya kewenangan untuk mengurusi kepentingan mereka. Disisi lain Akuntabilitas adalah kemampuan untuk mempertanggung jawabkan semua tindakan dan kebijaksanaan yang telah ditemapuh (Azlim et al., 2012; Mardiasmo, 2002).

Pengurus harian dan setiap devisi dalam kepengurusan pondok pesantren putri Al-Amien, mempunyai tugas dan wewenang masing- masing. Setiap pengurus bertanggung jawab dalam tugas masing- masing. Berdasarkan pengamatan selama 10 hari, pengurus yang terlihat paling berperan aktif dalam melaksanakan tugas setiap harinya adalah dari devisi pendidikan dan kebersihan. Dari devisi pendidikan mengeluarkan aturan bahwa batas maksimal tidak mengikuti jama'ah dan mengaji kitab umum adalah satu kali tiap minggunya. Setiap santri, jika lebih dari satu kali alfa atau 3 kali terlambat dalam melakukan sholat berjama'ah dalam satu minggu, maka setiap jum'at pagi akan dilaksanakan ta'ziran (hukuman) berdasarkan kebijakan pengurus. Jadi, pengurus akan keliling setiap kamar setiap kegiatan berlangsung untuk melihat siapa yang masih dikamar dan mengisi absen yang ditempel didepan setiap kamar. Dari devisi kebersihan membuat jadwal piket harian bagi setiap santri, bagi siapa saja yang tidak melaksanakan tugas piketnya maka akan didenda Rp. 5000 setiap satu kali meninggalkan piket.

Beberapa santri mengaku keberatan dengan banyaknya peraturan yang dibuat, tapi banyak juga yang setuju dengan kebijakan pengurus mendisiplinkan santri dan menjaga kebersihan pondok, seperti yang diungkapkan salah seorang santri bernama Indria I'ahimatul Mahsunah. Menurutnya adanya peraturan sangat penting bagi kehidupan pondok pesantren yang disiplin dan damai. Hal tersebut juga sebagai penghargaan untuk santri-santri yang disiplin. Namun yang kurang dalam masalah tanggung jawab adalah dari bendahara, para santri mengaku setiap akan membayar bulanan selalu sulit mencari bendahara, sedangkan dari pengurus lain tidak ada upaya mencarikan sang bendahara. Hal seperti ini dapat membuat peraturan yang telah dibuat dapat terlanggarkan, karena tugas sebagai pengurus (bendahara) memberikan pelayanan pada santri yang membutuhkan. Hal ini tidak harus segera dibenahi supaya sesuai dengan aturan yang ditentukan. Seperti belajar dikelas, seorang guru harus mengetahui situasi siswanya. Jika ada permasalahan, guru mudah ditemui (Surur, 
Rais, \& Habib, 2017). Begitu juga sebagai bendahara, membantu santri yang membutuhkan pelayanannya ketika dibutuhkan.

Secara umum, penerapan rasa tanggung jawab pengurus dan santri sudah baik. Santri tidak mengikuti kegiatan sadar akan konsekuensinya, dan tidak menolak ketika hari hukuman telah tiba. Pengurus juga bersikap objektif, pengurus yang tidak mengikuti kegiatan juga menerima hukuman.

\section{Keterbukaan (transparasi)}

Penerapan masalah keterbukaan berdasarkan pendapat para santri dirasa kurang baik. Dalam masalah pemilihan kepengurusan, pengurus bukan dipilih berdasarkan musyawarah, tetapi pengurus lama akan memilih pengurus bari dari orang-orang terdekatnya. Ini berdasarkan pemaparan seorang santri yang sudah cukup lama berada di ponpes Al- Amin. Tapi, jika dari devisi pendidikan, transparasi terlihat cukup bagus. Ini terbukti dengan adanya absen yang ditempel didepan kamar masingmasing. Jadi setiap santri mengetahui pelanggaran apa yang telah dilakukan dan berhak memprotes jika merasa tidak melakukan pelanggaran tersebut.

\section{Partisipasi}

Partisipasi santri dalam mengikuti setiap kegiatan sangat besar, ini bisa saja terjadi karena tingkat kesadaran santri akan kebutuhan pada ilmu memang tinggi, tapi juga bisa saja karena adanya sanksi-sanksi dalam setiap pelanggaran. Bahkan ada beberapa santri yang menggunakan semaksimal mungkin kesempatan tidak mengikuti kegiatan satu minggu sekali. Tapi dalam menetapkan peraturan, seluruhnya mengikuti perintah pengasuh. Pengasuh akan menetapkan peraturan dan memberitahukan kepada pengurus. Pengurus akan melakukan negosiasi jika dirasa peraturan kurang tepat bagi santri yang mayoritas adalah pelajar dan mahasiswa. Jadi, santri tidak pernah terlibat dalam penetapan peraturan dan pemilihan kepengurusan. Sehingga meskipun partisipasi santri dalam mengikuti setiap kegiatan yang ada sangat besar, namun santri yang melakukan pelanggaran tata tertib juga masih banyak.

4. Penegak Hukum (Rule of law)

Penegakan hukum menurut Arich Yatimmatur dirasa cukup objektif. Pengurus tidak hanya menghukum dari kalangan santri, tapi jika pengurus sendiri yang melakukan pelanggaran maka juga akan menerima hukuman. Santri juga berhak membela diri sebelum menerima hukuman. 


\section{Daya Tanggap (responsif)}

Tata tertib yang telah dibuat oleh pondok pesantren Al-Amin, ternyata hanya sebagai pajangan semata. Kebanyakan santri yang telah diwawancara, mereka pernah melanggar tata tertib. Walaupun ada yang tidak melanggar namun hanya sedikit. Kebanyakan dari mereka melanggar karena kondisional. Dalam peraturan telah disebutkan bahwa santri wajib mengikuti jamaah sholat maghrib, isya' dan subuh. Karena jika jamaah ke masjiid, akan menjadi makmum masbuk dan terkadang masjid juga penuh. Akhirnya jamaah di kamar. Selain itu banyak pelanggaran yang dilakukan santri, seperti halnya bagi santri MTsN dan MAN tidak diperbolehkan membawa hp, mereka kebanyakan masih membawa karena untuk komunikasi dengan teman mereka mengenai tugas dan keperluan lain. Dari banyak pelanggaran yang dilakukan santri mungkin kurang tegasnya pengurus keamanan dan kesadaran santri terhadap tata tertib yang ada.

\section{Orientasi konsensus (kesepakatan)}

Peraturan yang ada selama ini di pondok pesantren Al-Amien, yang membuat hanyalah pengasuh. Sementara para santri hanya menyetujui, jikalau merekan kurang setuju, mereka tetap tidak bisa berbuat apa-apa. Dikarenakan peraturan yang telah dibuat oleh pengasuh adalah mutlak dan harus dipatuhi para santri. Berdasarkan hal itu, keterbukaan dalam pembuatan peraturan kurang berjalan. Para santri tidak dilibatkan sama sekali oleh pondok pesantren. Sehingga adanya tata tertib hanyalah sekedar formalitas, sementara santri tetap banyak yang melanggar.

\section{Kesetaraan keadilan (equity)}

Berdasarkan pengamatan peneliti, pondok pesantren Al-Amien telah menjunjungtinggi kesetaraan keadilan dalam hal penegakan peraturan serta hukuman. Hukuman tetap diberikan kepada setiap santri yang melanggar tata tertib, dala hal ini tidak ada perbedaan kasta. Hal ini juga dibuktikan dengan adanya peraturan mengenai tidak diperbolehkan membawa hp yang memiliki fitur lebih kepada seluruh santri yang berstatus mahasiswa sedangkan bagi santri yang masih bersekolah tidak diperbolehkan membawa hp. Hal ini bertujuan agar tidak ada kesenjangan sosial diantara para santri.

8. Efektivitas (effectiveness) dan efesiensi (efficiency)

Kegiatan yang berkaitan dengan produktifitas tidak diterapkan dalam pondok pesantren Al-Amien. Santri hanya berkewajiban mengikuti setiap kegiatan yang ada. 
Dengan adanya tata tertib dan pembinaan akhlak di pondok pesantren Al-Amien, para santri diharapkan memilki moral yangbaik serta berguna ketika mereka terjun di lingkunganmasyarakat.

9. Visi strategis (strategic vision)

Dunia pesantren berorientasi pada kehidupan akhirat, sehingga perubahanperubahan kebijakan untuk menyongsong perkembangan dunia tidak begitu diperhatikan. Perubahan-perubahan peraturan hanya berfokus dalam menjaga nama baik pesantren dan pembentukan kedisiplinan mungkin inilah yang membuat pendidikan pesantren jarang mengalami kemajuan yang pesat sehingga menarik khalayak umum untuk lebih memililh bersekolah di pesantren daripada di sekolah umum.

\section{SIMPULAN DAN SARAN}

Secara garis besar, penerapan good governance yang ada di pondok pesantren AlAmien cukup bagus. Masih terlihat jelas adanya sikap otoriter dari pengasuh dalam menetapkan peraturan. Para santri tidak diberi kesempatan untuk ikut menyuarakan pendapat dalam membuat keputusan tata tertib. Atau bisa jadi, ini dikarenakan adanya rasa tawadhu' dari santri kepada pengasuh yang sangat besar, sehingga tidak mempunyai keberanian untuk bersuara. Hal ini membuat para santri banyak yang melanggar peraturan secara diam-diam. Namun, dari sistem kepengurusan terlihat cukup baik. Para pengurus tetap memberikan kelonggaran pada santri untuk menyuarakan pendapat dan membela diri. Partisipasi dan tanggung jawab dari santri sendiri sebagai masyarakat juga sudah cukup baik. Para santri berani melanggar tapi tetap siap menerima setiap konsekuensinya.

Untuk peneliti berikutnya dapat mengambil hal positif dari teori good governance tersebut sehingga dapat diterapkan di berbagai lembaga. Tidak hanya diterapkan dalam lembaga pendidikan, tetapi juga dapat dicoba dalam suatu organisasi atau keluarga. Bahkan untuk pemerintahan diri sendiri juga bisa. Peneliti berikutnya sebaiknya menambahkan unsur kuantitatif. Hal ini sebagai penguat data yang sudah diperoleh dari proses kualitatif. Sehingga corak penelitian menjadi mix kuantitatif-kualitatif. Hal ini dilakukan supaya hasil penelitian lebih akurat. 


\section{DAFTAR PUSTAKA}

Andalia, F., \& Setiawan, E. B. (2015). Pengembangan Sistem Informasi Pengolahan Data Pencari Kerja pada Dinas Sosial dan Tenaga Kerja Kota Padang. Jurnal Ilmiah Komputer Dan Informatika (Komputa), 4(2), 93-98.

Arifin, Z. (2015). Kepemimpinan Kiai dalam Ideologisasi Pemikiran Santri di Pesantren-Pesantren Salafiyah Mlangi Yogyakarta. Inferensi, 9(2), 351-372.

Arikunto, S. (1993). Prosedur Penelitian Ilmiah Suatu Pendekatan Praktik. Jakarta: Rineka Cipta.

Arikunto, S. (2005). Manajemen Penelitian. Jakarta: Rineka Cipta.

Asifudin, A. J. (2016). Manajemen Pendidikan untuk Pondok Pesantren. Manageria: Jurnal Manajemen Pendidikan Islam, 1(2), 355-366.

Atiqullah. (2012). Varian Kepemimpinan Kolektif Pondok Pesantren di Jawa Timur. Karsa, 20(1), 21-42.

Azlim, Darwanis, \& Bakar, U. A. (2012). Pengaruh Penerapan Good Governance dan Standar Akuntansi Pemerintahan terhadap Kualitas Informasi Keuangan SKPD di Kota Banda Aceh. Jurnal Akuntansi, 1(1), 1-14.

Dwiyanto, A. (2009). Mewujudkan Good Governance melalui Pelayanan Publik. Yogyakarta: Gajah Mada Univercity Press.

Fitriana, A., Irianto, G., \& Mulawarman, A. D. (2018). Studi Fenomenoligi tentang Good Pesantren Governance pada Pondok Modern Dasussalam Gontor, Ponorogo. Jurnal Ilmiah Akuntansi Peradaban, IV(1), 24-48.

Ja'far, A. K. (2018). Good Corporate Governance pada Lembaga Pendidikan Pesantren: Studi pada Pondok Pesantren Universitas Islam Indonesia. Akademika, 23(1), 197-216.

Kediri, T. P. B. P. K. I. S. (2009). Pedoman Penulisan Karya Ilmiah. Kediri: STAIN Kediri Press.

Mardiasmo. (2002). Akuntansi Sektor Publik. Yogyakarta: Andi.

Moleong, L. J. (2011). Metodologi Penelitian Kualitatif. Bandung: Remaja Rosdakarya.

Nugroho, R. (2004). Kebijakan Publik, Formulasi Implementasi dan Evaluasi. Jakarta: Gramedia.

Putra, N., \& Lisnawati, S. (2012). Penelitian Kualitatif Penelitian Agama Islam. Bandung: Remaja Rosda Karya.

Rahayu, N. W. I. (2014). Lembaga Amil Zakat, Politik Lokal, dan Good Governance Di Jember. Karsa, 22(2), 207-223.

Rasul, S. (2009). Penerapan Good Governance di Indonesia dalam Upaya Pencegahan Tindak Pidana Korupsi. Mimbar Hukum, 21(3), 538-553. 
Santosa, P. (2008). Administrasi Publik: Teori dan Aplikasi Good Governance. Bandung: Refika Aditama.

Santoso, G. (2005). Fundamental Metodologi Penelitian Kuantitatif dan Kualitatif. Jakarta: Prestasi Pusaka.

Sari, B. I., \& Yani, M. T. (2013). Gaya dan Tipologi Kepemimpinan Kiai di Pondok Pesantren Babussalam Dusun Kalibening, Desa Tanggalrejo, Mojoagung, Jombang. Kajian Moral dan Kewarganegaraan, 2(1), 253-267.

Sjaifudian, H. (2003). Inovasi Partisipasi dan Good Governance. Jakarta: Yayasan Obor Indonesia.

Surur, A. M., Rais, P., \& Habib. (2017). The Application Program of the Preparation of the Syllabus and Learning Implementation Plan (RPP) 2013 Curriculum on Teachers Madrasah Ibtidaiyah. In Proceeding International Conference on Islamic Education (ICIED) "Innovations, Approaches, Challenges, and the Future” (Vol. 2, pp. 246-253). Malang.

Trisnaningsih, S. (2007). Independensi Auditor dan Komitmen Organisasi sebagai Mediasi Pengaruh Pemahaman Good Governance, Gaya Kepemimpinan dan Budaya Organisasi terhadap Kinerja Auditor. In Simposium Nasional Akuntansi $X$ (pp. 1-56).

Ubaedillah, A. dan A. R. (2007). Demokrasi, Hak Asasi Manusia dan Masyarakat Madani. Jakarta: ICCE UIN Syarif Hidayatullah.

US., K. A. (2010). Kepemimpinan Kiai Pesantren: Studi terhadap Pondok Pesantren di Kota Jambi. Kontekstualita, 25(2), 225-254.

Wardianto, M., \& Hendrati, F. (2014). Korelasi Motivasi Berprestasi dan Kepemimpinan Transformasional dengan Komitmen Organisasi Pengurus Pondok Pesantren. Jurnal Psikologi Indonesia, 3(3), 269-282.

Wiguna, M., \& Putra, A. A. (2017). Analysis of Factors That Affect Good Government Governance Implementation (Empirical Study on Government of Indragiri Hilir Regency). Jurnal Akuntansi Keuangan dan Bisnis, 10(2), 70-78.

Wulandari, S. (2014). Pola Komunikasi Kyai di Pondok Pesantren. Jurnal Commonline Departemen Komunikasi, 3(3), 630-644.

Yusniyar, Darwanis, \& Abdullah, S. (2016). Pengendalian Intern terhadap Good Governance dan Dampaknya pada Kualitas Laporan Keuangan ( Studi pada SKPA Pemerintah Aceh ). Jurnal Magister Akuntansi, 5(2), 100-115. 